\title{
Correction to: DNA barcoding significantly improves resolution of invasive lionfish diet in the Northern Gulf of Mexico
}

\author{
Kristen A. Dahl · William F. Patterson III - Alison Robertson • \\ Alice C. Ortmann
}

Published online: 3 July 2018

(C) Springer International Publishing AG, part of Springer Nature 2018

\section{Correction to: Biol Invasions (2017) 19:1917-1933 https://doi.org/10.1007//10530-017-1407-3}

In the original publication, the Acknowledgements section has been published incorrectly.

The corrected Acknowledgements is given in this correction:

We thank Dalton Kennedy, Scott Bartel, Clint Retherford, Bryan Clark, Andy Ross, Anna Clark, Jeremy Porter, Michael Day and Kylie Gray for assistance acquiring lionfish samples for this study. We thank Lei

The original article can be found online at https://doi.org/10.1007/s10530-017-1407-3.

A. Robertson - A. C. Ortmann

Department of Marine Sciences, Dauphin Island Sea Lab, University of South Alabama, Dauphin Island, AL, USA

\section{K. A. Dahl $(\bowtie)$}

School of Natural Resources and Environment, University of Florida, Gainesville, FL, USA

e-mail: kristendahl@ufl.edu

W. F. Patterson III

Fisheries and Aquatic Sciences Program, School of Forest Resources and Conservation, University of Florida,

Gainesville, FL, USA

\section{A. C. Ortmann}

Department of Fisheries and Ocean Canada, Centre for Offshore Oil, Gas and Energy Research, Bedford Institute of Oceanography, Dartmouth, NS, Canada
Wang, Pearce Cooper, and Natalie Ortell for minor assistance with molecular equipment. We thank Joseph Tarnecki, Brian Klimek, Justin Lewis, Steve Garner, and Michael Norberg for assistance with the processing of whole lionfish. This research was made possible by a Grant from The Gulf of Mexico Research Initiative/C-IMAGE II and Mississippi Alabama Sea Grant (USM-GR03924-R-HCE-04-PD). Data are publicly available through the Gulf of Mexico Research Initiative Information and Data Cooperative (GRIIDC) at https://data.gulfresearchinitiative.org (https://doi.org/10.7266/N7F769ZD). Sequences are accessible through the National Center for Biotechnology Information (http://www.ncbi.nlm.nih.gov/). 